\title{
Lypsylehmien fosforiruokinnan tarkentaminen
}

\author{
Samu Palander ${ }^{1)}$, Susanna Tauriainen ${ }^{2)}$, Pekka Huhtanen ${ }^{3)}$, Kirsi Suhonen ${ }^{1)}$ ja Eero Mäkäräinen ${ }^{4)}$ \\ ${ }^{1)}$ Seinäjoen ammattikorkeakoulu, Maa- ja metsätalouden yksikkö, Ilmajoentie 525, 60800 Ilmajoki, \\ samu.palander@seamk.fi \\ ${ }^{2)}$ Opetushallitus, PL 380,00531 Helsinki,susanna.tauriainen@oph.fi \\ ${ }^{3)}$ MTT Eläinravitsemus,31600 Jokioinen,pekka.huhtanen@mtt.fi \\ ${ }^{4)}$ Rehumelica Oy, Frilundintie 2,65170 Vaasa, eero.makarainen@rehumelica.fi
}

\section{Tiivistelmä}

Lypsylehmien ruokinnassa on perinteisesti aina ollut fosforitäydennys. Suomalaiset lypsylehmien kivennäistarvenormit perustuivat aiemmin englantilaisiin 1960-luvulla laadittuihin normeihin, ja niissä fosforiruokinnan taso oli 4,5 g rehun kuiva-ainekiloa kohden. Kuitenkin viimeaikaisissa amerikkalaisissa tutkimuksissa on päädytty suosittelemaan 3,5 g fosforia rehun kuiva-ainekiloa kohti. Mitä ilmeisimmin meilläkin on varaa vähentää fosforiruokintaa ja näin ollen vähentää myös ympäristöön, pellolle päätyvää fosforin määrää.

Selvitysten mukaan tilaolosuhteissa lypsylehmien kalsiumin, fosforin, magnesiumin ja kaliumin saanti ylittää huomattavasti vanhojenkin ruokintanormien tason. Tämä tutkimus aloitettiin vuonna 2003. Suomalaisia fosforiruokintasuosituksia muutettiin vuonna 2004. Muutosperusteena olivat kuitenkin ulkomaiset tutkimukset ja normit, eikä kotimaisia fosforiruokintatuloksia ole ollut käytettävissä. Periaatteessa nykyiset normit täyttävä fosforin saanti toteutuu tyypillisestä säilörehua, viljaa ja rypsirouhetta sisältävästä ruokinnasta. Tämän tutkimuksen tavoitteena on pitkäaikaiskokeella tutkia fosforittoman kivennäisrehun käytön vaikutuksia lypsylehmien maidontuotantoon, terveyteen, hedelmällisyyteen ja lannassa erittyvän fosforin määrään. Tutkimuksessa on tarkoitus kerätä tietoja kaikilta kokeeseen tulevilta lehmiltä kolmen lypsykauden ajan. Tutkimus on tällä perusteella nyt hieman yli puolessa välissä, ja ensimmäiset välitulokset ovat käytettävissä.

Koe-eläiminä ovat Ilmajoen koulutilan lypsylehmät, jotka on jaettu kahdelle ruokintakäsittelylle: (1)fosforiton kivennäinen lypsäville lehmille ja ummessaoleville sekä sisä- että laidunruokintakaudella ja (2)tavanomainen, aikaisemmat suositukset täyttävä kivennäisruokinta. Muu rehustus on samanlainen kaikille. Kokeessa määritetään karjantarkkailun mukaiset tuotos-, tiinehtymis- ja terveystiedot. Lisäksi lehmiltä otetaan verinäytteet (kaulalaskimosta) ennen koetta, 2-3 kk ja 7-8 kk poikimisesta ja ainakin kerran kokeen aikana sontanäytteet. Veriplasmasta analysoidaan fosfori-, kalsium ja magnesiumpitoisuudet ja sonnasta fosforipitoisuus. Lisäksi kerätään ja analysoidaan rehunäytteitä kokonaisfosforin saannin arvioimiseksi.

Keskimäärin ryhmän 1 lehmät lypsivät ensimmäisellä tuotantokaudella (305 päivän tuotos) $6800 \mathrm{~kg}$ ja ryhmän 2 lehmät $6250 \mathrm{~kg}$. Ero ei kuitenkaan ollut tilastollisesti merkitsevä. Toiselta tuotantokaudelta lähes kaikilta lehmiltä oli käytettävissä 150 päivän tuotokset, eikä näissäkään havaittu merkitsevää eroa. Siemennyksiä tiinehtymistä kohti on tarvittu ryhmissä 1 ja 2 keskimäärin 2,9 ja 2,4; poikimavälit olivat vastaavasti 398 d ja 381 d. Erot eivät ole tilastollisesti merkitseviä. Korkean tuotannon vaiheessa fosforipitoisuus veressä näytti olevan ryhmällä 1 hieman matalampi kuin ryhmällä $2(1,554 \mathrm{mmol} / 1 \mathrm{vs.} 1,708 \mathrm{mmol} / \mathrm{l})(\mathrm{P}<0,1)$, mutta matalan tuotannon vaiheessa eroa ei ollut $(1,616 \mathrm{mmol} / 1$ vs. $1,665 \mathrm{mmol} / \mathrm{l})$. Veren kalsiumpitoissuuksissa ei ollut eroa ryhmien välillä $(2,525 \mathrm{mmol} / 1$ vs. $2,538 \mathrm{mmol} / 1$ korkean ja $2,575 \mathrm{mmol} / 1 \mathrm{vs.} 2,580 \mathrm{mmol} / \mathrm{l}$ matalan tuotannon vaiheessa). Veren magnesiumpitoisuudessa oli pieni, mutta merkitsevä, toistaiseksi selittämätön ero ryhmien välillä (korkean tuotannon vaiheessa $1,177 \mathrm{mmol} / 1$ vs. $1,087 \mathrm{mmol} / 1 ; \mathrm{P}<0,05$ ja matalan tuotannon vaiheessa $1,146 \mathrm{mmol} / 1$ vs. $1,054 \mathrm{mmol} / 1 ; \mathrm{P}<0,1)$.

\section{Asiasanat}

lypsylehmä, fosfori, kivennäisrehut 


\section{Johdanto}

Lypsylehmien ruokinnassa on perinteisesti aina ollut fosforitäydennys, ja fosforia sisältävää kivennäisrehua on käytetty sekä ummessaolo- että lypsylaudella. Suomalaiset lypsylehmien kivennäistarvenormit perustuivat aiemmin englantilaisiin 1960-luvulla laadittuihin normeihin, ja niissä fosforiruokinnan taso oli noin 4,5 g rehun kuiva-ainekiloa kohden (Tuori ym. 1996). Kuitenkin viimeaikaisissa amerikkalaisissa tutkimuksissa on päädytty suosittelemaan 3,5 g fosforia rehun kuiva-ainekiloa kohti (Wu ym. 2001).

Mitä ilmeisimmin meilläkin on varaa vähentää fosforiruokintaa ja näin ollen vähentää myös ympäristöön, pellolle päätyvää fosforin määrää. Viljavuuspalvelun tilastojen mukaan Suomessa peltojen fosforikuormitus on koko ajan lisääntynyt 1950-luvulta lähtien. Lisäksi fosforin yliruokinta on vanhojenkin normien suhteen Yrjäsen ym. (2003) mukaan hyvin yleistä. Tässä esiteltävä tutkimus on aloitettu vuonna 2003, mutta suomalaisia fosforiruokintasuosituksia muutettiin niukemmiksi vuonna 2004 (Rehutaulukot ja ruokintasuosotukset 2004). Tässä muutoksessa perusteena olivat kuitenkin ulkomaiset tutkimukset ja normit, eikä kotimaisia fosforiruokintatuloksia ole ollut käytettävissä.

Suuri osa lyspsylehmien fosforin saannista on peräisin maitotuotosta lisäävistä, taloudellisesti perusteltavista tekijöistä, kuten valkuaisrehujen käytöstä (Yrjänen ym. 2003). Periaatteessa nykyiset normit täyttävä fosforin saanti toteutuu tyypillisestä säilörehua, viljaa ja rypsirouhetta sisältävästä ruokinnasta, eikä fosforia tarvitsisi lisätä lehmien kivennäisrehuseoksiin. Tämän tutkimuksen tavoitteena on pitkäaikaiskokeella tutkia fosforittoman kivennäisrehun käytön vaikutuksia lypsylehmien maidontuotantoon, terveyteen, hedelmällisyyteen ja lannassa erittyvän fosforin määrän̈n. Tutkimuksessa on tarkoitus kerätä tietoja kaikilta kokeeseen tulevilta lehmiltä kolmen lypsykauden ajan. Tutkimus on tällä perusteella nyt hieman yli puolessa välissä, ja ensimmäiset välitulokset ovat käytettävissä.

\section{Aineisto ja menetelmät}

Koe-eläiminä ovat Ilmajoen koulutilan noin kolmekymmentä lypsylehmää, joita hoidetaan pihattonavetassa normaalien hoitokäytäntöjen mukaan ja käytetään opetuksessa. Lehmät on jaettu kahdelle ruokintakäsittelylle: (ryhmä 1)fosforiton kivennäisrehuseos lypsäville lehmille ja ummessaoleville sekä sisä- että laidunruokintakaudella ja (ryhmä 2)tavanomainen, aikaisemmat suositukset täyttävä kivennäisruokinta. Muuten rehustus on samanlainen molemmille ryhmille ja perustuu säilörehuun, ohra-kauraseokseen ja rypsirouheeseen. Käytössä on tasaväkirehuruokinta, joka suunnitellaan rehuanalyysitulosten perusteella täyttämään $8000 \mathrm{~kg}$ tuotostavoitteen edellyttämä ravinnontarve. Säilörehua on tarjolla vapaasti, ja yksilöllisen väkirehu- ja kivennäisrehuannoksensa lehmät saavat ryhmänsä mukaisesta väkirehukioskista.

Lehmiltä määritetään ja kirjataan lähinnä karjantarkkailun mukaiset tuotos-, tiinehtymis- ja terveystiedot. Lisäksi lehmiltä otetaan verinäytteet kaulalaskimosta ennen koetta, korkean tuotannon vaiheessa $(2-3 \mathrm{kk}$ poikimisesta) ja matalamman tuotannon vaiheessa $(7-8 \mathrm{kk}$ poikimisesta). Ainakin kerran kokeen aikana otetaan myös sontanäytteet. Verinäytteet sentrifugoidaan ja veriplasmasta analysoidaan fosfori-, kalsium ja magnesiumpitoisuudet. sontanäytteistä määritetään fosforipitoisuus. Lisäksi kerätään ja analysoidaan käyttöön tulevista rehueristä näytteet kokonaisfosforin saannin arvioimiseksi.

Lypsykausien 305 päivän maitotuotoksia (tässä vaiheessa ensimmäisen lypsykauden 305 päivän ja toisen lypsykauden 150 ensimmäisen päivän), veren kivennäispitoisuuksia, toteutuneiden siemennysten määrää tiineyttä kohti ja poikimaväliä verrattiin ryhmien välillä varianssianalyysillä. Veren kivennäisten ja siemennyskertojen tapauksessa ennen koetta määritettyjä tietoja käytettiin mallissa mukana kovariaattina. Kaikkien yksilöimättömien sorkkaongelmien ja todettujen tervesorkkaisten eläinten esiintymistä toteutuneissa sorkkahoidoissa tai -tarkastuksissa analysoitiin $\chi^{2}$-testillä.

\section{Tuloksia ja niiden tarkastelua}

Tutkimuksesta on käytettävissä ensimmäisiä välituloksia, joita tässä esitellään lyhyesti. Ensimmäisen tutkimuksessa toteutuneen lypsykauden 305 päivän maitotuotos ja toisen lypsykauden 150 ensimmäisen päivän maitotuotos on esitetty Taulukossa 1. Ensimmäisen kauden 305 päivän tuotokset olivat ryhmässä 1 (niukempi fosfori) keskimäärin lähes $500 \mathrm{~kg}$ korkeampia, mutta hajonta oli huomattavaa, eikä ero ollut tilastollisesti merkitsevä. Toiselta tuotantokaudelta lähes kaikilta lehmiltä oli käytettävissä 150 päivän tuotokset, eikä niissä näy eroa. Koska matalampikin fosforitaso täyttää käytettävissä olevan tiedon mukaan lehmien fosforitarpeen, ei ole odotettavissa, että tuotoksissa eroja olisikaan.

Veriplasman fosfori-, kalsium- ja magnesiumpitoisuudet ensimmäisellä tuotantokaudella erosivat ryhmien välillä jonkin verran (Taulukko 2.) Korkean tuotannon vaiheessa fosforipitoisuus veressä näytti olevan ryhmällä 
1 hieman matalampi kuin ryhmällä $2(\mathrm{P}<0,1)$, mutta matalan tuotannon vaiheessa eroa ei ollut. Matalampi veren fosforitaso niukemmalla fosforiruokinnalla olleilla eläimillä on ymmärrettävää. Veren kalsiumpitoissuuksissa ei ollut eroa ryhmien välillä. Veren magnesiumpitoisuus oli niukemman fosforin saannin ryhmässä n. $0,01 \mathrm{mmol} / 1$ korkeampi. Lukemat mahtuvat normaalivaihtelun sisään, mutta ero oli tilastollisesti merkitsevä (korkean tuotannon vaiheessa $\mathrm{P}<0,05$ ja matalan tuotannon vaiheessa $\mathrm{P}<0,1)$. Mikäli ero säilyy jatkossa, voi olla syytä selvittää, voiko fosforin saannilla olla vaikutusta magnesiumaineenvaihduntaan.

Siemennyksiä tiinehtymistä kohti on tarvittu ryhmissä 1 ja 2 keskimäärin 2,9 ja 2,4, ja poikimavälit olivat vastaavasti 398 d ja 381 d. Erot eivät ole tilastollisesti merkitseviä. Eritasoisten sorkkavikojen osuus tutkituista lehmistä on ollut $55 \%$ ryhmässä 1 ja $69 \%$ ryhmässä 2 . Osuudet ovat suuria, mutta niissä ovat mukana vähäisetkin sorkkahoitajan raportoimat viat, eikä merkitsevää eroa sorkkavikojen esiintymisessä ryhmien välillä ole.

\section{Johtopäätökset}

Välitulosten perusteella fosforittoman kivennäisseoksen käytöllä ja siten matalammalla fosforitasolla ei näyttäisi olevan vaikutusta lypsylehmien tuotokseen, terveyteen ja hedelmällisyyteen, kuten on oletettukin. Tutkimuksen edistyessä mainituista parametreista saadaan kuitenkin vielä huomattavasti lisää aineistoa, mikä mahdollistaa paremmin johtopäätösten esittämisen.

Taulukko 1. Ensimmäisen lypsykauden 305 päivän maitotuotos ja toisen lypsykauden 150 ensimmäisen päivän maitotuotos $/ \mathrm{kg}( \pm \mathrm{SEM})$.

\begin{tabular}{|lll|}
\hline & Ryhmä 1 & Ryhmä 2 \\
Tuotos 305 päivää & $6802 \pm 265$ & $6259 \pm 294$ \\
Tuotos 150 päivää & $4259 \pm 223$ & $4286 \pm 242$ \\
\hline
\end{tabular}

Taulukko 2. Veriplasman kivennäispitoisuudet korkean ja matalan tuotannon vaiheessa $/ \mathrm{mmoll}^{-1}( \pm \mathrm{SEM})$.

\begin{tabular}{|lllllllll|}
\hline \multicolumn{9}{c}{ Korkea tuotanto } \\
& Ryhmä 1 & Ryhmä 2 & $\mathrm{P}_{\text {lähẗtas }}$ & $\mathrm{P}_{\text {ryhmä }}$ & Ryhmä 1 & Ryhmä 2 & $\mathrm{P}_{\text {lähtötaso }}$ & $\mathrm{P}_{\text {ryhmä }}$ \\
$\mathrm{P}$ & $1,55 \pm 0,06$ & $1,71 \pm 0,06$ & & $\mathrm{o}$ & $1,62 \pm 0,11$ & $1,67 \pm 0,11$ & & \\
$\mathrm{Ca}$ & $2,53 \pm 0,03$ & $2,53 \pm 0,03$ & & $*$ & $2,58 \pm 0,03$ & $2,58 \pm 0,03$ & \\
$\mathrm{Mg}$ & $1,18 \pm 0,03$ & $1,09 \pm 0,03$ & $\mathrm{o}$ & $*$ & $1,15 \pm 0,03$ & $1,06 \pm 0,04$ & $\mathrm{o}$ & $\mathrm{o}$ \\
\hline
\end{tabular}

\section{Kirjallisuus}

Rehutaulukot ja ruokintasuositukset 2004 märehtijät - siat - siipikarja - turkiseläimet - hevoset. MTT:n selvityksiä 86. 82 p. verkkojulkaisu: http://www.mtt.fi/mtts/pdf/mtts86.pdf

Tuori, M., Kaustell, K., Valaja, J., Aimonen, E., Saarisalo, E. \& Huhtanen, P. 1996. Rehutaulukot ja ruokintasuositukset. Märehtijät - siat - siipikarja - turkiseläimet - hevoset. 99 p. Yliopistopaino, Helsinki.

Yrjänen, S., Nousiainen, J.I., Kytölä, K., Khalili, H. \& Huhtanen, P. 2003. Ruokinnalliset mahdollisuudet parantaa fosforin hyväksikäyttöä maidontuotannossa. In: Jaana Uusi-Kämppä, Markku Yli-Halla ja Kaarina Grék (toim.). Lypsykarjataloudesta tulevan ympäristökuormituksen vähentäminen. Maa- ja elintarviketalous 25: s. 13-25. verkkojulkaisu: http://www.mtt.fi/met/pdf/met25.pdf

Wu, Z., Satter, L.D., Blohowiak, A.J., Stauffacher, R.H. \& Wilson, J.H. 2001. Milk production, estimated phosphorus excretion and bone characteristics of dairy cows fed different amounts of phosphorus for two or three years. J. Dairy Sci. 84: 1738-1748. 